\title{
Educational Leadership in Latin Europe: A European Perspective
}

\section{Lejf Moos}

Aarhus Universitet - København - Department of Education (Denmark)

doi: 10.7358/ecps-2015-011-moos

moos@dpu.dk

\section{LEADERSHIP EDUCATIVA NELL'EUROPA LATINA: \\ UNA PROSPETTIVA EUROPEA}

\section{Abstract}

Much of the contemporary literature and theory of leadership has, as its starting point, the image of governance and public school leadership, an image that is very close to the vision proposed by the OECD. This view is strongly influenced by the way the neo-liberal AngloAmerican approach analyzes and outlines the political and administrative characteristics of school organization. However, you cannot apply the same practices and policies all over the world, such as in the countries of Latin America. This general introduction is put forward with a framework in which we can reflect their own situation. It cannot be realistic to have a "one size fits all" policy such as the method of governance the OECD implies. An important addition to the traditional Anglo-American perspective presented in these pages is the discussion on the fact that strong leadership from above can be replaced by a perspective of distributed leadership, inserting the concepts of leadership within social contexts and a broader policy.

Keywords: Distribution, Governance, Leadership, OECD, Societal context, Transnational agencies.

The following description is very general as it focuses on the relations of global and transnational agencies and national stakeholders and is adapted from (Moos, 2009 and 2013).

Governance analyses (Dean, 1999) have established that it is not possible to govern a nation, its institutions or even its individuals by economic and 
administrative regulation through legislation only. This understanding is being supplemented, or perhaps even replaced, by the understanding that societies cannot be governed from one point, i.e. the government. Governments and other authorities must see themselves as «leaders of leaders» that lead through indirect forms of power in complex, "polyphonic settings" (Pedersen, 2005). These forms of governance are meant to influence the ways in which institutions and individuals perceive, interpret, understand and act. The actions themselves become less important in this perspective. The values and norms that inform actions are more important from a governmental point of view, because indirect forms of power attempt to influence values and norms.

Supra- and transnational agencies such as the OECD and the European Commission have therefore developed soft forms of governance. Those agencies are not - when it comes to education and its governance and politics commissioned to use direct forms of governance, like regulations.

Globalisation is an intricate pattern of changes in economics and in the global division of labour (e.g. the emergence of more than 50,000 massive transnational companies, which are loyal to their shareholders and therefore able to force governments to shape their financial policies according to market logics). Other sources of influence are the changes in communication (especially the Internet and other forms of split-second, global mass media); changes in politics (with only one global political system remaining), and changes in culture. More recent areas that are affected by global interdependencies are the financial market, the climate and the environment.

One can detect strong tendencies towards designing a new global marketplace with few or no barriers for cross-country operations: the free flow of finances, goods and workers (Pedersen, 2010). The prime driver for this deregulation of cooperation was the neo-liberal economy; hence, the core logics and theories of the new world order were economic: public choice, rational choice, principal-agent, transaction cost theory and scientific management.

The German philosopher and sociologist Jürgen Habermas (2001) writes that societies engaged in the process of financial globalisation tend to possess four characteristics (author's translation):

- An anthropological view of human beings as rational instruments willing and able to make informed decisions and to offer their labour freely in the market place.

- An image of a post-egalitarian society that tolerates social marginalisation, expulsion and exclusion.

- An image of a democracy where citizens are reduced to consumers in a market-society, and where the role of the state is redefined to that of a service agency for clients and consumers.

- Finally, a view that policy should be aimed at dismantling state regulation. 
These are building bricks for a neo-liberal picture of the world, says Habermas. The latter element would seem to challenge the very basis of democracy. If Habermas is correct in his depiction of the neo-liberal effort to transform policy-driven societies into market-driven societies, there have to be fundamentally new conditions for institutions, citizens and democracy.

One global effect is the trend towards neo-liberal market politics (with a focus on decentralisation, output, competition and strong leadership) as well as accountability politics in the public sphere (with a focus on re-centralisation and centrally imposed standards and quality criteria). This trend is known as New Public Management (NPM) (Hood, 1991; Moos, 2006).

Barriers between nations in the areas of economics, industry and trade, and culture and communication have been torn down, and new relationships and new coalitions and liaisons have been formed. Some of these new relationships are ad hoc; some are more formal. Most of them have been established primarily to promote economic cooperation. The G8 (the coalition of France, Germany, Italy, Japan, the UK, the US, Canada and Russia), the World Bank, the OECD and the EU are just a few of these powerful agencies.

\section{Supra- AND TRANSNATIONAL AGENCIES}

The OECD and the European Commission are two powerful players in the global field of educational politics. They have so far not been positioned to make educational policy regulation on behalf of member governments. However, this fact might change with respect to the EU due to the Lisbon Agreement. National policies are influenced by supra-national EU policies «that create, filter and convey the globalisation process» (Antunes, 2006).

Since both agencies - and their member governments - are interested in international collaboration and inspiration, they have developed alternative methods for influencing the thinking and regulation of education in member states. The EU has developed the open method of coordination, and the OECD a method of peer pressure (Schuller, 2006).

At the European Commission's meeting in Lisbon, participants agreed to develop a flexible method based on reflexivity and indicators. This method should include flexible governance tools that rely on soft law. A major feature of the open method is reflexivity; member states and institutions should inspire each other through peer reviews and policy learning, e.g. best practices. An important tool is a set of indicators meant to enable the identification of best practice (Lange \& Alexiadou, 2007). 
CERI (Centre for Educational Research and Innovation), the OECD bureau that manages education and educational research, is a powerful player in the globalisation of economies and, thereby, the restructuring of nationstates.

These influences on policy and practices are not linear and straightforward. Lingard (2000) describes them as "mutually constitutive relations» between distinctive fields, or spaces. The main influence comes from the OECD setting the agenda, both within the whole organisation - e.g. international comparisons such as PISA (Programme for International Student Assessment) and TIMSS (Trends in International Mathematics and Science Study) - and within individual member nations. If a government wants to put an issue on the national agenda, but lacks the strength to do so on its own, it can call on the OECD for help. The OECD then forms a team that reviews the state of affairs in the member state, based on a detailed and comprehensive framework designed by the OECD. The team's report often forms the basis for political action in the states.

This strategy is explicated in the OECD publication Education catalogue (OECD , 1998) as a strategy of "peer pressure» that «encourages countries to be transparent, to accept explanations and justification, and to become selfcritical».

Both agencies distinguish between hard governance and soft governance. The choice of terms is interesting, because hard law/governance stands for regulations that influence people's behaviour, while soft law/governance influences the way people perceive and think about themselves and their relationships with the outside world. Soft governance therefore influences agents in much deeper ways. While these methods of influence might seem softer, or more educational, the effects of soft influence are harder and more profound.

Accompanying soft governance, transnational agencies develop social technologies that national governments build on, adjust and use in their endeavour to influence public sector institutions and practitioners. Social technologies are technologies with a purpose or an aim. It can be routines, manuals, methods and tools that very often conceal the aims. The social technologies used by the two transnational agencies seem to follow the same pattern, which builds on the liberal core concept of citizens' (or consumers') choice, presupposing that citizens are given a screen, a background, upon which to make their choices. Therefore, there must be comparisons between competitors and, eventually, some kind of indicators that can function as yardsticks for making the selection, the national interpretations.

Transnational influences are, as mentioned, forms of soft governance: advice, discourses etc. These are to some degree taken in by the national political and administrative systems and transformed to national policies, 
reinventing national education. However, something central spills over. When joining international comparison programmes, like PISA or TIMSS, national governments take over international standards and let them replace national standards

\section{THE OECD AND SCHOOL LEADERSHIP}

One of the themes that has been take up and treated as a "peer pressure» exercise by the OECD is school leadership (Pont, Nusche, \& Moorman, 2008). The official Power Point slide (OECD, 2008b) gives a good introduction to the ways the agency looks at school leadership and thus on the ways national governments are encouraged and supposed to work (Figure 1).

There are three main categories in the OECD school leadership worldview: school autonomy, accountability for outcomes and learning centered leadership.

The first category, school autonomy, builds on OECD analyses that governance of schools is gradually being decentralized, so more and more decisions are allocated to schools by national or local governing agencies. (OECD, 2008a). However, the analyses show that this is true for many countries, but not for Latin Europe for which talking about autonomous schools seems not to be relevant at this point in time.

\section{School autonomy}

- «Running a small business»

- Managing human and financial resources

- Adapting to teaching programme

Accountability for outcomes

- A new culture of evaluation

- Strategic planning, assessment, monitoring

- Use data for improvement

Learning-centred leadership

- New approaches to teaching and learning

- Supporting collaborative teaching practice

- Raising achievement and dealing with diversity

Figure 1. - "OECD: The changes: the role of school leadership is evolving dramatically [...]" (OECD, 2008b). 
This questions the very foundation of the school leadership model laid out by the OECD, and it makes discussions on autonomy very difficult as people will have diverse backgrounds and understandings in this regard. On the other hand, it will leave room for interpretation to be filled by politicians, policymakers, researchers and practitioners.

In countries, where decentralization is implemented, we also see mixed images. It is often only the management of resources that has been decentralized, while the leadership and interpretation of educational and learning goals has been re-centralized, so that the central government - by setting detailed standards and national tests - has taken back governance over the curriculum and also accountability procedures. School leadership is not only framed by the governance system in which it is embedded, but also by its educational discourse (Figure 2).

\section{+ Educational Gover nance Perspective}



Figure 2. -Educational Governance Perspective, 2015.

\section{INFLUENCE FROM A SCHOOL LEADERSHIP PERSPECTIVE}

In line with the decentralization tendencies, described below, we can see (adapted from Moos, 2014, forthcoming) that a near consensus is being created in leadership theory on the need for distributed leadership (Spillane, 2006; Moos, 2009). The understanding emerges that the principal cannot be sufficiently informed to make all decisions in a school, nor can she/he be 
present in all places and situations where decisions need to be made. This is eminently the case in classrooms, where teachers have to interpret demands, goals and situations and make decisions many times in every lesson. It is also the case in teacher teams that meet to plan, evaluate their instruction or engage in professional development. If the principal is not present, she/he is excluded from making decisions, although naturally she/he can construct the frameworks within which teams maneuver.

However, as Spillane (2006) notes, distributed leadership can take many forms. At the core of their concept of leadership is the notion that leadership is not the actions of the leaders per se, but the interactions between leaders and other agents. Leadership is therefore a relationship of influence between leaders and followers that takes place in situations, to be described by their tools, routines and structures. Leadership is about interactions that influence and that are understood to influence other persons.

One important aspect of school leadership tasks can be summed up in this way: leadership is setting and negotiating directions, making sense. Even though schools in some systems are managed in some detail when it comes to outcomes, standards, inspections and tests, they have to find the ways to achieve these outcomes themselves. They have to interpret demands and signals from the outer world and choose the means by which they want to respond to them. It is a major challenge to school leadership to interpret signals and make them into narratives: communications about differences which form the premises for the next decisions in the community (Weick, 1995 and 2001; Thyssen, 2003).

This can also be expressed as a deliberative practice, in line with what Karen Seashore Louis writes:

Many contemporary democratic theorists argue that the most essential element of democratic communities today is their ability to engage in civilized but semi-permanent disagreement. Articulating a humanist voice that calls for respecting and listening to all positions - but then being able to move forward in the absence of consensus - will be the critical skill that school leaders need to develop when the environment makes consensus impossible. (Louis, 2003)

\section{CONCLUSiON}

Mainstream leadership models from the OECD underscore the need for strong leadership and also the need for a clear and transparent use of data, accountability and documentation. Those expectations belong to societies where the hierarchy is clear and mostly undisputed. In this kind of societies, 
leaders set the direction and measure the outcomes of schooling and teaching. Tools and social technologies are developed for that purpose. National learning standards and bench-marks, tests and documentation, best practices and evidence are some of them. Also tools for managing relations between leaders and teachers are developed, like economic incentives, staff appraisals and staff-interviews. However, it is pivotal to bear in mind that leadership is, at its very core, the enactment of relations that support all actors to make sense of the external expectations. Therefore, many different kinds of negotiations and distributed leadership styles are developed in schools.

\section{REFERENCES}

Antunes, F. (2006). Globalisation and Europeification of education policies: Routes, processes and metamorphoses. European Educational Research Journal, 5(1), $38-55$.

Dean, M. (1999). Governmentality: Power and rule in modern society. London: Sage. Habermas, J. (2001). Warum braucht Europa eine Verfassung?, Die Zeit, 28. Juni.

Hood, C. (1991). A public management for all seasons. Public Administration, 69, Spring, 3-19.

Lange, B., \& Alexiadou, N. (2007). New forms of european governance in the education sector? A preliminary analysis of the open method of coordination. European Educationa Research Journal, 6(4), 321-335.

Lingard, B. (2000). It is and it isn't: Vernacular globalization, educationa. Policy, and restructuring. In N. C. Burbules \& C. A. Torres (Eds.), Globalization and education. Critical perspetives. New York: Routledge.

Louis, K. S. (2003). Democratic schools, democratic communities. Leadership and Policy in Schools, 2(2), 93-108.

Moos, L. (2006). Fra politiske demokratidiskurser mod markedsorienterede effektivitetsdiskurser. Nordisk Pedagogik, 26(4), 322-332.

Moos, L. (2009). Hard and soft governance: The journey from transnational agencies to school leadership. European Educational Research Journal, 8(3), 397-406.

Moos, L. (2013). Prelude: Tuning the instrument. In L. Moos (Ed.), Transnational influences on values and practices in Nordic educational leadership - Is there a Nordic model? Dordrecht: Springer.

Moos, L. (2014, forthcoming). Leadership for creativity. International Journal of Leadership in Education, forthcoming.

OECD (1998). Education catalogue. Paris: OECD.

OECD(2008a). Education at a glance. Paris: OECD. 
OECD (2008b). Improving school leadership. Official Power Point presentation, 2013. Paris: OECD. Retrieved (25/03/2015) from: http://www.oecd.org.

Pedersen, D. (2005). Ledelsesrummet i managementstaten. In D. Pedersen (Hg.), Offentlig ledelse i managementstaten. Frederiksberg: Samfundslitteratur.

Pedersen, O. K. (2010). Konkurrencestaten. København: Hans Reitzels Forlag.

Pont, B., Nusche, D., \& Moorman, H. (2008). Improving school leadership: Policy and practice. Paris: OECD.

Schuller, T. (2006). Reviewing OECD's educational research reviews. European Educational Research Journal, 5(1), 57-61.

Spillane, J. P. (2006). Distributed leadership. San Fransisco: Jossey-Bass.

Thyssen, O. (2003). Luhman og ledelsen. In H. Højlund \& M. Knudsen (Hg.), Organiseret kommunikation - Systemteoretiske analyser. Frederiksberg: Samfundslitteratur.

Weick, K. E. (1995). Sensemaking in organizations. Thousands Oaks, CA: Sage.

Weick, K. E. (2001). Making sense of the organization. Malden, MA: Blackwell.

\section{Riassunto}

Gran parte della letteratura specialistica e sulla teoria contemporanea della leadership ha come punto di partenza l'immagine del governo pubblico e della dirigenza scolastica, un'immagine che è molto vicina alla vision proposta dall'OCSE. Questo punto di vista ancora una volta è fortemente influenzato dal modo neo-liberale anglo-americano di analizzare e delineare le caratteristiche politiche e amministrative dell'organizzazione scolastica. Ciò significa che non può applicarsi a pratiche e politiche in tutto il mondo, come nei Paesi dell'Europa latina. La presente introduzione generale viene avanzata con uno schema di riferimento entro il quale si può riflettere la propria situazione. Non può infatti essere realistico che una "taglia unica" possa andar bene a tutti, cosi come il metodo di governo dell'OCSE implica. Un'importante aggiunta alla prospettiva tradizionale anglo-americana presentata in queste pagine è la discussione in merito al fatto che una forte leadership dall'alto possa essere sostituita da una prospettiva di leadership distribuita, inserendo i concetti di leadership nell'ambito di contesti sociali e politici piu ampi.

Parole chiave: Agenzie transnazionali, Contesto sociale, Distribuzione, Governance, Leadership, OCSE. 